\title{
Program Pemberdayaan Small And Medium Enterprise Promotion (SMEP) Oleh Swisscontact
}

\author{
Empowerment Program Small and Medium Enterprise Promotion (SMEP) by \\ Swisscontact
}

\author{
Al Briham Jarmal ${ }^{1}$, Murdianto ${ }^{2}$ \\ ${ }^{1}$ Departemen Sains Komunikasi dan Pengembangan Masyarakat FEMA IPB \\ ${ }^{2}$ Dosen Departemen Sains Komunikasi dan Pengembangan Masyarakat FEMA IPB
}

\begin{abstract}
This research purpose was to analyze the empowerment strategy in Small and Medium Enterprise (SMEP) program and to analyze the empowerment process in SMEP program. This program has operated by Swisscontact (one of the international NGO), and the beneficiaries is a denim cluster in Cipulir. This method research was qualitative method and sampling method was snowball sampling. The result was empowering strategy that Swisscontact use is facilitation strategy. It means the denim cluster in Cipulir is already knows what they problem but they don't know how to solve it. This strategy make Swisscontact has an agent of change in this SMEP program. The second result was, empowering process in this program split in two phases. First is primer process, in this process the denim cluster in Cipulir having a training to improve their productivity. Second is secondary process, in this process the denim cluster in Cipulir having a group discussion with Swisscontact and other players in this area. The discussion purpose is to encourage and motivated them during this program.
\end{abstract}

Key Words : empowering, strategy, process, SMEP

\section{Abstrak}

Penelitian ini bertujuan untuk menganalisis strategi pemberdayaan pada program Small and Medium Enterprise (SMEP) dan untuk menganalisis proses pemberdayaan pada program SMEP. Program ini dijalankan oleh SwissContact (salah satu NGO internasional), dan penerima manfaat adalah kelompok usaha kecil Jins di Cipulir. Metode yang digunakan pada penelitian ini adalah metode kualitatif dengan metode pengambilan sampel adalah metode snowball. Hasil dari strategi pemberdayaan yang digunakan oleh Swisscontact adalah strategi fasilitasi. Ini artinya kelompok usaha kecil Jins di Cipulir telah mengetahui permasalahan mereka namun mereka tidak mengetahui cara memecahkannya. Strategi ini menjadikan Swisscontact sebagai agen pembaharuan pada program SMEP ini. Hasil kedua dari penelitian adalah proses pemberdayaan dalam program ini dibagi atas dua tahap. Tahap pertama adalah proses primer, pada proses ini kelompok usaha kecil Jins di Cipulir diberikan sebuah pelatihan untuk mengembangkan produksinya. Kedua merupakan proses sekunder, dalam proses ini kelompok usaha kecil Jins di Cipulir memiliki sebuah kelompok diskusi dengan Swisscontact dan pemain lainnya di area tersebut. Tujuan diadakan diskusi adalah untuk mengembangkan dan memotivasi mereka selama program berlangsung.

Kata kunci: Pemberdayaan, Strategi,SMEP

\section{Pendahuluan}

Krisis ekonomi yang melanda Indonesia pada tahun 1997, telah meruntuhkan banyak usaha besar akan tetapi tidak dengan UMKM (Usaha Mikro, Kecil dan Menengah). Sebagian besar UMKM tetap bertahan, bahkan jumlahnya meningkat dengan pesat dan perhatian pada UMKM menjadi lebih besar. Kuatnya daya tahan UMKM juga didukung oleh struktur permodalannya yang lebih banyak tergantung pada dana sendiri. Jumlah UMKM sejak tahun 1997 sampai sekarang meningkat dengan cepat dibandingkan dengan usaha berskala besar. UMKM sendiri dapat menyerap tenaga kerja yang lebih banyak dibandingMelihat sumbangannya pada perekonomian yang semakin penting, UMKM seharusnya mendapat perhatian yang semakin besar dari para pengambil kebijakan, khususnya lembaga pemerintahan 
yang bertanggung jawab atas perkembangan UMKM. Akan tetapi, upaya pengembangan yang dilakukan oleh pemerintah belum bisa mengembangkan para pelaku UMKM. Pengembangan UMKM di Indonesia selama ini dilakukan oleh Kantor Menteri Negara Koperasi dan Usaha Kecil Menengah (Kementerian Negera KUMKM).

Departemen Keuangan melalui SK Menteri Keuangan Menkeu No.316/KMK.016/1994 mewajibkan BUMN untuk menyisihkan 1-5 persen laba perusahaan bagi Pembinaan Usaha Kecil dan Koperasi (PUKK), namun kebanyakan BUMN memilih persentase terkecil, yaitu 1 persen, sementara banyak UMKM yang mengaku kesulitan mengakses dana tersebut. Selain itu, kredit perbankan juga sulit untuk diakses oleh UMKM, diantaranya karena prosedur yang rumit serta banyaknya UMKM yang belum bankable. Apalagi Bank Indonesia tidak lagi membantu usaha kecil dalam bidang permodalan secara langsung dengan diberlakukannya UU Nomor 23 Tahun 1999 tentang Bank Indonesia. Selain permasalahan yang sudah disebutkan sebelumnya, secara umum UMKM sendiri menghadapi dua permasalahan utama, yaitu masalah finansial dan masalah nonfinansial (organisasi manajemen). Masalah yang termasuk dalam masalah finansial diantaranya adalah :

1. Kurangnya kesesuaian antara dana yang tersedia yang dapat diakses oleh UMKM.

2. Tidak adanya pendekatan yang sistematis dalam pendanaan UMKM.

3. Biaya transaksi yang tinggi, yang disebabkan oleh prosedur kredit yang cukup rumit sehingga menyita banyak waktu sementara jumlah kredit yang dikucurkan kecil.

4. Kurangnya akses ke sumber dana yang formal, baik disebabkan oleh ketiadaan bank di pelosok maupun tidak tersedianya informasi yang memadai.

5. Bunga kredit untuk investasi maupun modal kerja yang cukup tinggi.
6. Banyak UMKM yang belum bankable, baik disebabkan belum adanya manajemen keuangan yang transparan maupun kurangnya kemampuan manajerial dan finansial. Masalah yang termasuk dalam masalah organisasi manajemen (nonfinansial) di antaranya adalah :

1. Kurangnya pengetahuan atas teknologi produksi dan quality control yang disebabkan oleh minimnya kesempatan untuk mengikuti perkembangan teknologi serta kurangnya pendidikan dan pelatihan.

2. Kurangnya pengetahuan pemasaran, yang disebabkan oleh terbatasnya informasi yang dapat dijangkau oleh UMKM mengenai pasar.

3. Keterbatasan sumber daya manusia.

4. Kurangnya pemahaman mengenai keuangan dan akuntansi

Disamping dua permasalahan utama, UMKM juga menghadapi permasalahan linkage dengan perusahaan dan ekspor. Ada beberapa strategi yang dapat diterapkan untuk mengatasi problema tersebut kepada UMKM, salah satunya adalah strategi pemberdayaan masyarakat yang dilakukan untuk memperkuat kelembagaan sosial, politik, ekonomi dan budaya masyarakat, dan memperluas partisipasi masyarakat miskin, baik laki-laki maupun perempuan, dalam pengambilan keputusan kebijakan publik yang menjamin penghormatan, perlindungan dan pemenuhan hak-hak dasar. Dalam hal ini, Swisscontact sebagai salah satu lembaga asing yang beroperasi di Indonesia, berperan untuk mengatasi problem kemiskinan dengan strategi pemberdayaan masyarakat melalui sektor ekonomi.

Upaya yang dilakukan oleh Swisscontact adalah dengan menerapkan program pengembangan Usaha Mikro, Kecil dan Menengah (UMKM). UMKM dipilih karena sebagian besar pelaku UMKM merupakan masyarakat miskin, diharapkan dengan meningkatnya potensi bisnis yang ada dapat memberikan dampak langsung terhadap pengurangan kemiskinan. Kegiatan 
ini bertempat di Cipulir, Jakarta Selatan terdapat UMKM yang bergerak di bidang tekstil. Proyek ditempatkan di Cipulir yang dimana ada sekitar 1.000 produsen, 1.500 pedagang dan beratus-ratus usaha dengan industri pendukung didalamnya, seperti: laundry, sulam-menyulam, para penyalur permesinan didalam kelompok ini, dengan mempekerjakan sekitar 10.000 pekerja tetap dan 5.000 pekerja paruh waktu.

Situasi ekonomi dari usahawan kecil dan mikro di area ini berpotensi untuk dikembangkan. UMKM ini mulai berkembang pada awal tahun 2007. Akan tetapi, bencana banjir yang melanda Jakarta pada bulan Februari 2007 menghancurkan kelompok industri rumahan ini yang melahirkan suatu program Small Textile Enterprise Promotion (STEP) oleh Swisscontact. Program ini memfokuskan pada rehabilitasi dengan memberikan 800 mesin usaha kepada 400 kelompok usaha di Cipulir. Akan tetapi kelompok usaha yang telah mendapatkan bantuan dari program STEP ini tetap harus dikembangkan karena tingginya persaingan di sektor tekstil, karena bantuan hanya bersifat sementara saja. Beberapa permasalahan, seperti ketidaktahuan terhadap variasi dan disain inovatif yang mengakibatkan suatu kecenderungan untuk menghasilkan produk serupa, ketidaktahuan terhadap mutu produk, organisasi dan koordinasi yang lemah di dalam kelompok usaha yang mengakibatkan kompetisi yang tidak adil baik bagi produk maupun bagi karyawan, dan kemampuan tentang keuangan yang terbatas dan ketidaktahuan tentang manajemen bisnis dan kemampuan administrasi (tata buku dan arus kas manajemen), menjadi permasalahan yang sering dialami oleh para pelaku UMKM di Cipulir.

Swisscontact merancang suatu program untuk mengatasi masalah tersebut, dalam rangka melanjutkan program sebelumnya, yang dinamakan Small and Medium Enterprise Promotion (SMEP) Jakarta. Program ini bertujuan untuk memperbaiki keadaan kelompok usaha setelah terjadi bencana banjir dan untuk meningkatkan pendapatan usaha. Sejauh mana program SMEP telah memberdayakan kelompok usaha kecil di Cipulir inilah yang akan menjadi fokus permasalahan dari penelitian ini. Berdasarkan latar belakan tersebut, maka perumusan masalah yang akan dikaji dari program Small and Medium Enterprise Promotion (SMEP) Jakarta adalah: Bagaimana strategi pemberdayaan dari program Small and Medium Enterprise Promotion (SMEP) Jakarta telah memberdayakan UMKM di Cipulir? Serta Bagaimana proses pemberdayaan pada program Small and Medium Enterprise Promotion (SMEP) Jakarta telah memberdayakan UMKM di Cipulir?

\section{Metodologi Penelitian}

Penelitian ini menggunakan metode kualitatif dimana melalui pendekatan ini peneliti berusaha mengeksplor fenomenafenomena yang tidak dapat dikuantifikasikan yang bersifat deskriptif seperti proses suatu langkah kerja, dalam penelitian ini adalah untuk menggambarkan strategi pemberdayaan dan proses pemberdayaan dari program Small and Medium Enterprise Promotion (SMEP) yang dilaksanakan oleh Swisscontact. Penelitian dilaksanakan di dua lokasi, lokasi pertama yaitu di kantor Swisscontact dan lokasi kedua bertempat di Cipulir, Jakarta Selatan. Informan yang dipilih yaitu orang yang mengetahui tentang informasi secara keseluruhan mengenai program Small and Medium Enterprise Promotion (SMEP), yaitu karyawan Swisscontact itu sendiri. Informan disini ialah Pak Ad (Ketua Program SMEP) dan Ibu Mr (Wakil Ketua Program SMEP).

Responden merupakan para pelaku usaha kecil di Cipulir yang menerima program SMEP. Responden dipilih secara sengaja (purposive). Responden terdiri dari tiga orang dari tiap-tiap ketua kelompok usaha kecil yang ada di Cipulir. Mereka adalah Bapak Nsr (ketua kelompok usaha kecil daerah Padang), Bapak Asm (ketua kelompok usaha kecil daerah Karawang), dan Bapak Mht (ketua kelompok usaha kecil 
daerah Purworejo). Ketiga responden ini dipilih karena ketiganya merupakan pelaku usaha kecil di Cipulir yang mengikuti program SMEP dari tahap awal hingga selesai. Teknik pengumpulan data yang dilakukan oleh peneliti adalah pengambilan data primer dan data sekunder. Data primer diperoleh di lapangan melalui wawancara mendalam.. Data sekunder didapat dari analisis dokumen mengenai laporan tentang program Small and Medium Enterprise Promotion (SMEP).

Data hasil pengamatan dan wawancara disajikan dalam bentuk catatan harian. Analisis data tersebut dilakukan dengan tiga cara yaitu reduksi data, penyajian data, dan penarikan kesimpulan. Reduksi data yang dimaksudkan adalah proses pemilihan, pemusatan perhatian pada penyederhanaan, pengabstrakan, dan transformasi data "kasar" yang muncul dari catatan harian. Proses ini berlangsung terusmenerus selama penelitian berlangsung bahkan sebelum data benar-benar terkumpul. Data dapat disajikan dalam bentuk teks naratif, matriks, dan juga bagan apabila memungkinkan untuk menjelaskan tujuan penelitian.

\section{Hasil Dan Pembahasan}

\section{Gambaran Umum Program Small and Medium Enterprise Promotion (SMEP)}

Salah satu program dari Swisscontact dalam membantu pengembangan UMKM di Indonesia adalah dengan adanya program SMEP yang berlokasi di Jakarta, tepatnya di daerah Cipulir. Seperti dijelaskan sebelumnya, Cipulir merupakan tempat berkumpulnya industri garmen terbesar yang ada di Jakarta. Program SMEP telah berjalan dari tahun 2007 sampai sekarang. Banjir besar yang melanda pada kota Jakarta pada bulan Februari tahun 2007 dijadikan momentum yang tepat oleh Swisscontact dalam melaksanakan program sekaligus mempromosikannya kepada para pelaku usaha kecil di Cipulir. Dalam upaya mempromosikan programnya, Swisscontact mengambil perhatian para pelaku usaha kecil dengan memberikan bantuan berupa penggantian mesin jahit sebanyak 800 mesin kepada 400 pelaku usaha kecil. Sebelum program ini dilaksanakan, Swisscontact melakukan survei untuk mengklasifikasikan para pelaku UMKM secara keseluruhan yang berada di Cipulir. Hasil dari pengklasifikasian ini adalah dengan membagi kelompok usaha menjadi tiga, yaitu usaha skala mikro, skala kecil, dan skala menengah. Pada program ini, Swisscontact memfokuskan hanya pada usaha skala kecil saja, karena usaha kecil dianggap paling berpotensi untuk dikembangkan (dibahas dalam bab selanjutnya).

Tujuan dari program ini adalah untuk meningkatkan daya kompetitif dari para pelaku usaha kecil di Cipulir. Dimana target dari program ini adalah 200 usaha kecil jins, dan bertujuan untuk menambah 400 pekerja harian dan 200 pekerja paruh waktu didalamnya. Hal ini bertujuan untuk meningkatkan pendapatan perusahaanperusahaan dan keluarga pekerja sampai 25 persen. Pengaruh dari peningkatan daya kompetitif ini akan melebihi perbaikan mata pencaharian untuk 200 industri manufaktur dan diperkirakan akan meningkatkan pendapatan mereka.

\section{Strategi Pemberdayaan Program Small And Medium Enterprise Promotion (Smep)}

\section{Strategi Pemberdayaan}

$\begin{array}{ccr}\text { Program Small and Medium } & \text { and } \\ \text { Enterprie Promotion (SMEP) yang }\end{array}$ dilakukan oleh Swisscontact kepada para Usaha Kecil yang berada di Pasar Cipulir bertujuan untuk meningkatkan kesejahteraan para pelaku Usaha Kecil. Usaha kecil menjadi sorotan utama dalam program ini, karena Swisscontact menganggap sektor ini yang mempunyai potensi untuk dikembangkan lebih lanjut. Usaha kecil di daerah Cipulir ini memproduksi celana jins khususnya untuk anak-anak. Permasalahan yang biasanya dihadapi oleh usaha kecil, 
khususnya pada bidang garmen adalah kemampuan tentang keuangan yang terbatas (kemampuan manajemen dan administrasi), ketidaktahuan terhadap mutu produk, desain yang tidak inovatif dan lemahnya akses pada bahan baku.

Dalam pelaksanaannya, Swisscontact mempunyai strategi pemberdayaan yaitu strategi fasilitasi. Strategi fasilitasi sendiri adalah strategi yang dipergunakan bila kelompok yang dijadikan target mengetahui ada masalah dan membutuhkan perubahan dan ada keterbukaan terhadap pihak luar dan keinginan pribadi untuk terlibat. Kasus yang terjadi di Pasar Cipulir adalah para pelaku usaha kecil telah mengetahui dan sadar akan permasalahan yang terjadi pada mereka, dan mereka membutuhkan adanya bantuan dan dukungan melalui program-program bantuan. Melalui strategi ini, Swisscontact dapat bertindak sebagai fasilitator. Oleh karena itu, tugas dari fasilitator ini seringkali membuat kelompok target menjadi sadar terhadap pilihan-pilihan dan keberadaan sumber-sumber. Strategi ini dikenal sebagai strategi kooperatif, yaitu agen peubah bersama-sama kliennya mencari penyelesaian yang terjadi di Pasar Cipulir.

\section{Identifikasi Kelompok Sasaran}

Langkah pertama yang dilakukan oleh Swisscontact dalam melakukan program SMEP adalah dengan mengidentifikasi kelompok sasaran yang akan dituju. Identifikasi kelompok sasaran sendiri adalah upaya untuk menemukan calon sasaran program yang sesuai dengan kriteria yang telah ditentukan.Pada pelaksanaannya, proses pengidentifikasian kelompok sasaran sepenuhnya dilakukan oleh Swisscontact. Pada awalnya, Swisscontact melakukan identifikasi kelompok usaha yang berada di Pasar Cipulir, dan didapatkan hasil sebagai berikut :

1. Usaha Mikro : Jumlah unit usaha mikro yang ada di Pasar Cipulir berjumlah 348 unit dengan jumlah pekerja antara dua sampai sepuluh pekerja, dan total keseluruhan unit mikro ini dapat menyerap tenaga kerja berjumlah 1740 orang (rata-rata lima orang per unit usaha). Jumlah produksi yang dapat dihasilkan per tahun sebanyak 40.000 sampai 60.000 potong, dengan net profit 20 sampai 30 persen dan pertumbuhan penjualan nol sampai satu persen per tahun.

2. Usaha Kecil : Jumlah unit usaha kecil yang ada di Pasar Cipulir berjumlah 203 unit dengan jumlah pekerja antara 11 sampai 30 pekerja, dan total keseluruhan unit kecil ini dapat menyerap tenaga kerja berjumlah 4060 orang (rata-rata 20 orang per unit usaha). Jumlah produksi yang dapat dihasilkan per tahun sebanyak 70.000 sampai 80.000 potong, dengan net profit 10 sampai 20 persen dan pertumbuhan penjualan lima sampai 10 persen per tahun.

3. Usaha Menengah : Jumlah unit usaha menengah yang ada di Pasar Cipulir berjumlah 29 unit dengan jumlah pekerja lebih dari 30 pekerja, dan total keseluruhan unit menengah ini dapat menyerap tenaga kerja berjumlah 1450 orang (rata-rata 50 orang per unit usaha). Jumlah produksi yang dapat dihasilkan per tahun sebanyak 100.000 sampai 300.000 potong, dengan net profit 10 sampai 20 persen dan pertumbuhan penjualan 10 sampai 20 persen per tahun.

Dalam penentuan klasifikasi para pelaku UMKM ini, Swisscontact tidak mempunyai data acuan dari lembagalembaga lain. Pengklasifikasian ini terlahir murni berdasar pada kondisi nyata yang ada di lapangan. Alasan Swisscontact tidak mengacu pengklasifikasian UMKM dari lembaga manapun, adalah supaya hasil data yang didapat benar-benar sesuai dengan kondisi sebenarnya.

Pada program SMEP, kelompok usaha yang mendapat bantuan hanya kelompok yang masuk dalam pengklasifikasian kelompok usaha kecil. Alasannya karena, diantara ketiga klasifikasi usaha tersebut hanya usaha kecil yang mempunyai kompetensi untuk dikembangkan. Pada usaha mikro, skala pendapatan pedagang masih sangat kecil, 
mereka pun tidak terlibat dalam proses pengerjaan produksi dari awal sampai barang jadi. Mereka hanya bertugas untuk menjual barang jadi saja di Cipulir. Sedangkan pada usaha menengah, usaha ini dirasa sudah cukup mandiri. Mereka sudah dapat bertahan dengan persaingan pasar.

Pada usaha menengah mereka sudah tidak mengalami penurunan omset yang signifikan. Oleh karena itu, program ini hanya berkonsentrasi pada usaha kecil, dimana pada usaha kecil mereka sudah mengerjakan proses produksi dari awal hingga barang jadi. Tetapi mereka mempunyai masalah dalam berproduksi, misalnya jaringan pemasaran yang masih rendah dan tingkat produktivitas yang rendah. Langkah berikutnya adalah dengan mensosialisasikan program ini kepada para pelaku usaha kecil di Cipulir. Pada tahap identifikasi kelompok sasaran, dapat terlihat belum adanya partisipasi dari para penerima program. Para penerima program hanya mendapatkan informasi awal mengenai pelaksanaan kegiatan identifikasi kelompok sasaran yang diinformasikan oleh koperasi yang berada di Cipulir.

\section{Penentuan Masalah dan Perencanaan Partisipatoris}

Pada tahap penentuan masalah dan perencanaan partisipatoris, diperlukan dalam proses pemberdayaaan karena seringkali lembaga atau instansi yang akan memberdayakan masyarakat belum mengenal dengan baik kondisi masyarakat yang menjadi sasaran program. Dalam merencanakan kegiatan-kegiatan yang berkaitan dengan upaya pemberdayaan, pihak yang terlibat harus memperhatikan kondisi yang dialami oleh pihak yang akan diberdayakan dan potensi yang dimilikinya. Sehingga kegiatan-kegiatan yang direncanakan dapat berjalan efektif dan efisien.

Pada pelaksanaanya di lapangan, upaya yang dilakukan Swisscontact adalah dengan mengadakan Focus Group Discussions (FGD). FGD sendiri bertujuan untuk mendapatkan visi dan misi bersama dalam menjalankan program ini. Dalam proses ini, secara otomatis merupakan sarana untuk menggali permasalahan dan potensi yang dimiliki oleh kelompok usaha kecil serta merencanakan kegiatan-kegiatan yang akan dilakukan selanjutnya. FGD, dihadiri oleh para pelaku usaha kecil di Cipulir, dan dihadiri pula oleh lembaga-lembaga terkait di sekitar usaha kecil ini. Pada tahap ini, setiap peserta FGD diberikan peluang untuk terlibat aktif dalam mengidentifikasi masalah-masalah apa saja yang mereka alami selama berusaha di Cipulir. Swisscontact dalam tahap ini hanya sebatas memfasilitasi dan memberikan arahan. Seperti yang dikatakan oleh Bapak Asm, 44 tahun (ketua kelompok usaha kecil daerah Karawang) :

“...pada saat rapat Pak Ade

(ketua program SMEP)

memberikan pengarahan dan langsung menanyakan keluhan apa aja yang ada sama Usaha Kecil di Pasar Cipulir, kita semua dikasih kesempatan buat ngomong semua keluhan yang ada...".

Setelah proses FGD selesai maka didapatkan empat permasalahan yang akan dicari penyelesaiannya secara bersama. Permasalahan tersebut adalah :

1. Tingkat produktivitas yang rendah.

2. Jaringan pemasaran yang rendah.

3. Akses yang rendah terhadap bahan baku.

4. Tidak adanya dukungan dari lembaga-lembaga terkait.

Permasalahan pada tingkat produktivitas yang rendah muncul akibat, ketidaktahuan para pelaku usaha mengenai manajemen kerja pada usaha garmen. Hal ini menyebabkan produksi menjadi tidak efisien dan menghasilkan kualitas produk yang tidak bagus sehingga permintaan pada produk rendah. Pada permasalahan yang kedua, terkait dengan permasalahan yang pertama yaitu dengan kualitas produk yang tidak bagus, maka jaringan pasar para pelaku usaha hanya terbatas di daerah Cipulir dan sekitarnya, walaupun ada beberapa produk yang didistribusikan ke Tanah Abang dan 
luar Jawa namun jumlahnya tidak banyak. Hal ini menyebabkan jumlah permintaan hanya ramai menjelang hari raya Idul Fitri saja. Kemudian pada permasalahan yang ketiga adalah akses terhadap bahan baku yang rendah, bahan baku yang didapat mempunyai kualitas yang urang bagus dan juga biaya yang dikeluarkan untuk bahan baku hampir setengah dari biaya produksi. Hal ini terjadi masih terkait dengan permasalahan yang pertama yaitu tingkat produktivitas yang rendah sehingga pendapatan usaha sedikit yang menyebabkan bahan baku hanya bisa dibeli dengan sistem "utang" dan sisa pembayaran akan dikenai bunga yang lumayan besar tiap bulannya. Permasalahan yang terakhir adalah tidak adanya kepedulian dari lembaga-lembaga terkait di sekitar usaha kecil di Cipulir.

Empat permasalahan yang muncul pada saat FGD berlangsung, sesuai dengan apa yang diinginkan oleh para pelaku usaha kecil, mereka benar-benar diberi keleluasaan berpendapat tentang keluhan yang selama ini dirasakan pada saat berusaha. Partisipasi sangat terasa pada tahap ini, tidak seperti tahap sebelumnya. Pada proses ini, para pelaku usaha kecil di Cipulir terlibat dalam proses analisis perencanaan kegiatan dan memiliki kontrol terhadap keputusan dan pelaksanaan kegiatan. Setelah proses FGD selesai maka Swisscontact membagi para pelaku usaha kecil berdasarkan suku/ras daerah masing-masing. Ada tiga kelompok suku yang dominan yaitu, Padang, Karawang, dan Purworejo, dengan ketuanya masing-masing adalah Pak Nsr (ketua kelompok Padang), Pak Asm (ketua kelompok Karawang), dan Pak Mht (ketua kelompok Purworejo). Pembagian kelompok berdasarkan suku dipilih karena mereka sudah mempunyai perkumpulan atau organisasi sendiri dan ada pertemuan rutin tiap bulannya, sehingga lebih mudah dari pihak Swisscontact untuk memberikan program.

Masalah yang sering dihadapi oleh para pemberi program ketika ingin mengembangkan UMKM, adalah karateristik para pelaku usaha kecil yang ingin perubahan terjadi secara cepat. Untuk mengatasi masalah tersebut, maka strategi Swisscontact memberikan pelatihan yang intensif kepada masing-masing ketua kelompok untuk dapat menerapkan pada usahanya, dimana nantinya tiap-tiap ketua kelompok ini akan mentransfer pengetahuan mereka tentang bagaimana berusaha yang baik kepada para anggotanya dan tiap-tiap kelompok rata-rata memiliki 100 sampai 125 pelaku usaha. Setelah berhasil mengadakan FGD antara para pelaku usaha kecil dengan lembaga-lembaga terkait, maka area intervensi yang akan diperbaiki oleh Swisscontact terkait dengan program SMEP, adalah :

Berdasarkan Tabel 1, Swisscontact bersama dengan para pelaku usaha kecil menentukan langkah-langkah nyata untuk menyelesaikan permasalahan tersebut berdasarkan area intervensi masing-masing. Pada area inervensi peningkatan produktivitas maka langkah nyata pada area ini adalah dengan melakukan penguatan dan peningkatan kapasitas para pelaku. Bentuknya adalah dengan mengadakan pelatihan yang terbagi menjadi dua tahap. Tahap pertama adalah pelatihan manajemen kerja dan tahap kedua adalah pelatihan manajemen keuangan.

Tabel 1 Area Intervensi Pada Program SMEP

\begin{tabular}{ll}
\hline Area intervensi & Keterangan \\
\hline Meningkatkan Produktivitas & Mengefisienkan biaya produksi \\
& Meningkatkan manajemen bisnis dan operasional \\
& Peningkatan ketrampilan teknis \\
Meningkatkan Akses Pasar & Meningkatkan informasi pasar \\
& Penguatan Business Linkage: Peningkatan komunikasi, kapasitas, manajemen bisnis dll. \\
Penguatan Services Providers & Promosi \\
& BDS Triasa \\
& IGTC (International Garmen Training Center) \\
\hline
\end{tabular}


Penguatan dan Peningkatan Kapasitas
Pelaku

Berdasarkan empat permasalahan yang ada, langkah pertama adalah dengan menyelesaikan permasalahan yang pertama, yaitu tingkat produktivitas yang rendah. Untuk mengatasi permasalahan yang paling utama, diperlukan intervensi yang dilakukan kepada para pelaku-pelaku usaha kecil di Pasar Cipulir. Pelaku disini mencakup produsen, pedagang, penyedia bahan baku, dan lembaga terkait lainnya. Namun, pelaku yang menjadi sorotan utama dalam program ini adalah produsen, dimana produsen merupakan pelaku utama dalam dunia usaha kecil di Cipulir. Bentuk intervensi yang dilakukan oleh Swisscontact kepada para pelaku usaha berupa pelatihan, baik itu pelatihan untuk masalah manajemen kerja, manajemen keuangan maupun pelatihan teknis tentang bagaimana menjahit dengan waktu dan cara yang lebih efisien, menjahit dengan model-model baru yang lebih modern, dan lain-lain. Dengan adanya pelatihan ini diharapkan para pelaku usaha nantinya dapat bekerja lebih cepat, efisien dan diharapakan keluaran akhir dari pelatihan adalah kualitas produk yang menjadi lebih bagus. Perubahan lain yang diharapkan oleh Swisscontact adalah dengan berubahnya manajemen keuangan dengan pembukuan arus kas yang lebih jelas sehingga para pelaku usaha akan lebih mudah jika menginginkan pinjaman/bantuan modal dari bank.

\section{Promosi Klaster}

Langkah berikutnya yang dilakukan oleh Swisscontact dalam menyelesaikan masalah yang ada pada para pelaku usaha di Cipulir adalah dengan cara mempromosikan klaster/kelompok usaha kecil ini. Promosi klaster ini dilakukan dengan cara memperluas jaringan pasar yang ada pada para pelaku usaha kecil di Pasar Cipulir. Langkah ini akan dilakukan jika strategi pertama telah selesai. Karena terkait dengan permasalahan yang pertama, yaitu jaringan pasar yang sedikit disebabkan karena kualitas produk yang kurang bagus. Sebelum adanya program bantuan dari Swisscontact, jaringan pasar para pelaku usaha kecil di Pasar Cipulir telah dijelaskan sebelumnya hanya terbatas di daerah sekitar Pasar Cipulir, sebagian didistribusikan ke Tanah Abang, dan beberapa ke luar pulau Jawa, dan biasanya siklus pembelian/pemesanan barang meningkat pada saat hari raya Idul Fitri saja, setelah itu tingkat pemesanan akan menurun drastis. Untuk itu diperlukan promosi dari para pelaku usaha kecil di Pasar Cipulir, agar jaringan pasar lebih luas.

Langkah selanjutnya adalah, Swisscontact bermitra dengan beberapa usaha garmen dalam skala besar. Upaya ini dilakukan sebagai bentuk kerja sama antar usaha besar dan usaha kecil dalam sektor garmen. Teknis pelaksanaannya adalah para pekerja usaha kecil mendapatkan pelatihan langsung oleh usaha garmen berskala besar. Pelatihan ini bertujuan agar para pegawai usaha kecil dapat menjahit sesuai dengan standar dari usaha garmen skala besar, dan pada akhirnya order atau pemesanan yang diterima oleh usaha skala besar dapat dilimpahkan sebagian kepada para pelaku usaha kecil, sehingga pendapatan mereka akan meningkat.

\section{Replikasi dari Para Pihak Yang Tertarik untuk Pengembangan Klaster}

Tahap ini bertujuan untuk mendukung semua intervensi yang akan dilaksanakan pada program ini, maka Swisscontact perlu bermitra dengan lembaga-lembaga yang ada di sekitar lingkungan usaha kecil di Pasar Cipulir. Lembaga yang telah bermitra selama program berlangsung adalah:

1. Microsoft berkontribusi dalam pengadaan komputer dalam program CTC (Communication and Training Centers), dengan tujuan dari program ini untuk memasarkan CTC kepada para 
pelaku usaha di Pasar Cipulir agar mereka dapat mencari informasi terkait dengan peningkatan pemasaran produk.

2. BDS Triasa Menyediakan layanan jasa konsultasi bisnis dan penyedia CTC.

3. IGTC (International Garment Training Centers) menyediakan pelatihan secara gratis kepada wirausaha yang direkomendasikan dari tiap-tiap kelompok. Program pelatihan meliputi pengetahuan tentang mesin jahit, identifikasi, proses produksi, dan monitoring.

4. Universitas dan Program Pemerintah Nasional. Universitas Bina Nusantara berpartisipasi dalam pemberian pelatihan kepada para pelaku program SMEP, dimana program ini dibiayai oleh program pemerintah. Mahasiswa Universitas Bina Nusantara yang memberikan pelatihan berjumlah sepuluh orang dengan waktu intensif selama lima bulan. BRI menyediakan bantuan pinjaman kepada pelaku Usaha Kecil.

5. Departemen Pendidikan mempromosikan program pemberdayaan kepada para pemuda di Cipulir melalui pembiayaan pelatihan menjahit.

6. JaCC (Jakarta City Center) mengidentifikasi pelaku usaha dan mengembangkan mesin-mesin jahit.

7. Bali Nirwana Limited Company memfasilitasi implementasi kemitraan antara Usaha Skala Kecil dengan Usaha Skala Besar.

8. Pemerintah Lokal Jakarta menyediakan bazar kepada para pelaku usaha. Bazar itu sendiri akan dilaksanakan dua kali dalam setahun.

Proses Pemberdayaan Program Small And Medium Enterprise Promotion (Smep)

\section{Proses Pemberdayaan}

Proses pemberdayaan mengandung dua kecenderungan: Pertama, proses pemberdayaan menekankan pada proses memberikan atau mengalihkan sebagian kekuasaan, kekuatan, atau kemampuan kepada masyarakat agar individu yang bersangkutan menjadi lebih berdaya. Proses ini dapat dilengkapi dengan upaya membangun aset material guna mendukung pembangunan kemandirian melalui organisasi. Proses ini disebut sebagai kecenderungan primer dari makna pemberdayaan. Kedua, kecenderungan sekunder, menekankan pada proses menstimuli, mendorong, atau memotivasi agar individu mempunyai kemampuan atau kerberdayaan untuk menentukan apa yang menajdi pilihan hidupnya melalui proses dialog. Sesungguhnya diantara kedua proses tersebut saling terkait. Agar kecenderungan primer dapat terwujud, seringkali harus melalui sekunder terlebih dahulu. Proses inilah yang digunakan oleh Swisscontact dalam menjalankan program Small and Medium Enterprise Promotion (SMEP) kepada para pelaku usaha kecil di Cipulir.

\section{Proses Pemberdayaan Sekunder}

Pada proses sekunder, dimana penekanan proses pemberdayaan terlihat dari bentuk-bentuk seperti menstimuli, mendorong, dan memotivasi agar para pelaku usaha kecil sadar bahwa dirinya mempunyai kemampuan untuk berdaya. Proses ini dapat dilihat dari usaha yang dilakukan oleh Swisscontact kepada para pelaku usaha kecil mulai dari Focus Group Discussion (FGD) yang diadakan pertama kali pada awal tahun 2008. Seperti yang dijelaskan pada bab sebelumnya, para peserta FGD diberikan keleluasaan berpendapat tentang keluhan-keluhan yang dialami selama menjalani usahanya. Partisipasi sangat terlihat pada proses pencarian masalah dan penentuan langkahlangkah atau strategi yang akan dilakukan untuk mengatasinya. Pada proses sekunder ini, kegiatan yang dilakukan oleh Swisscontact kepada para pelaku usaha kecil di Cipulir adalah dengan melakukan konsultasi dan evaluasi pada program ini. 
Evaluasi dilakukan sejalan dengan konsultasi. Pertemuan ini dilakukan dengan cara FGD yang dibagi menjadi dua tahap. Tahap pertama, Swisscontact mengadakan pertemuan FGD bersama dengan para pelaku usaha kecil di Cipulir. Sedangkan tahap kedua, Swisscontact mengadakan pertemuan FGD bersama dengan lembaga-lembaga yang bermitra dengan Swisscontct pada program SMEP. Pertemuan diskusi ini diadakan setiap enam bulan sekali, hal ini diperlukan agar program yang telah diterima para pelaku usaha dapat dikontrol dan tidak melenceng dari tujuan awal program dan dapat dilihat perkembangannya.

\section{Proses Pemberdayaan Primer}

Proses selanjutnya yang dilakukan
adalah dengan memberikan atau mengalihkan sebagian kekuasaan, kekuatan, atau kemampuan kepada masyarakat agar individu yang bersangkutan menjadi lebih berdaya. Proses ini berupa pelatihanpelatihan kepada para pelaku usaha kecil. Pelatihan-pelatihan ini berupaya untuk menyelesaikan permasalahan yang telah disebutkan pada bab sebelumnya, yaitu tingkat produktivitas yang rendah, jaringan pasar yang rendah, akses bahan baku yang rendah dan tidak adanya dukungan dari lembaga-lembaga terkait. Pelatihan ini merupakan turunan tiga langkahlangkah/intervensi yang telah disusun oleh Swisscontact bersama dengan para pelaku usaha kecil di Cipulir lewat FGD, yaitu penguatan dan peningkatan kapasitas pelaku, promosi klaster, dan replikasi dari para pihak yang tertarik untuk pengembangan klaster. Dalam melakukan pelatihan ini, Swisscontact bermitra dengan lembagalembaga terkait, antara lain IGTC, Universitas Bina Nusantara, Microsoft, dan BDS Triasa.

Pelatihan ini dibagi menjadi dua tujuan berdasarkan langkahlangkah/intervensi yang akan dilakukan pada program SMEP. Pertama, pelatihan ditujukan untuk menjawab intervensi penguatan dan peningkatan kapasitas pelaku, yaitu dengan adanya pelatihan manajemen kerja dan pelatihan manajemen keuangan. Sedangkan pelatihan yang kedua adalah untuk menjawab intervensi promosi klaster, yaitu dengan adanya penguatan koperasi, pembentukan CTC, dan pelatihan oleh PT Bali Nirwana.

\section{Kesimpulan}

Strategi pemberdayaan yang dilakukan oleh Swisscontact dalam program Small and Medium Enterprise Promotion (SMEP) kepada para pelaku usaha kecil di Cipulir dalam upaya memberdayakan UMKM yang mereka jalankan, menggunakan strategi fasilitasi. Maksudnya adalah para pelaku usaha kecil sudah mengetahui permasalahan yang mereka hadapi dan peran dari Swisscontact adalah hanya sebagai fasilitator atau agen peubah dalam program ini.

Proses pemberdayaan yang dilakukan oleh Swisscontact dalam program Small and Medium Enterprise Promotion (SMEP) kepada para pelaku usaha kecil di Cipulir adalah dengan menggunakan proses kecenderungan primer dan proses kecenderungan sekunder. Bentuk dari proses primer adalah dengan adanya pelatihan manajemen kerja dan manajemen keuangan pada para pelaku usaha kecil di Cipulir. Selain pelatihan tersebut, pada proses ini juga dilakukan penguatan koperasi, bantuan program CTC, dan melakukan mitra kerja dengan usaha garmen skala besar. Sedangkan proses sekunder, bentuknya adalah dengan mengadakan Focus Group Discussion (FGD) yang diadakan tiap bulan dan dihadiri oleh Swisscontact, pelaku usaha dan lembaga-lembaga terkait. Perubahan yang terjadi pada pelaku usaha kecil di Cipulir antara lain meningkatnya tingkat produktivitas, jaringan pemasaran yang bertambah, biaya bahan baku yang semakin rendah, dan adanya dukungan dari lembagalembaga terkait. 


\section{Daftar Pustaka}

Ife J. 1995. Community Development. Creating community alternativesvision analysis and practice. Australia: Longman. .

NasdianFT. 2003. Pengembangan Masyarakat. Bogor: Bagian IlmuIlmu Sosial, Komunikasi dan Ekologi Manusia. Departeman Ilmu-Ilmu Sosial Ekonomi. Fakultas Pertanian IPB.

Pranarka dan Moeljarto. 1996. Pemberdayaan dan Prosesnya. Diakses dari http://www.lfip.org. Kamis, 6 Agustus 2009.

RuditoBdan Budimanta A. 2003. Metode dan Teknik, Pengelolaan Community Development. Jakarta(ID): ICSD.

Satori D. 2009. Metode Penelitian Kualitatif. Bandung(ID): Alfabeta.

Siregar N. 2004. Tugas Pokok dan Fungsi Direktorat Jenderal PMD Depdari Dalam Upaya Pemberdayaan Potensi Ekonomi Lokal. Makalah pada Stadium General dan Monev ProyekCERD - DEPDAGRI bagi Mahasiswa Penerima Beasiswa Program MPM IPB. Jakarta. 